\title{
Čistá voda - zdravé město: Využitelnost stávajícího systému sběru informací pro naplnění cílů projektu
}

\section{STANISLAV JURÁŇ, MILENA FOREJTNÍKOVÁ, LUCIE VYSLOUŽILOVÁ, KATEŘINA SOVOVÁ}

Klíčová slova: kvalita povrchových vod - říční sedimenty - zdroje znečištění - tematické databáze

\section{SOUHRN}

Příspěvek představuje část projektu Čistá voda - zdravé město, který se zabývá predikcí možného výskytu nebezpečných chemických látek v tocích při haváriích a povodních. Seznamuje $s$ databázemi, které jsou v současné době k danému tématu vedeny, a s jejich praktickou využitelností. Na prrípadu VItavy v Praze, lidské činnosti i způsobů hospodaření v povodí nad tímto městem popisuje možnosti predikce výskytu nebezpečných látek v úseku toku $v$ hlavním městě. Zdůvodňuje nutnost zavedení dočasných sledovacích profilů pro potřeby řešení výzkumného úkolu a navrhuje zásady pro doplnění stávajících monitorovacích sítí a databází zdrojů znečištění tak, aby mohl být lépe posuzován vztah mezi zdroji znečištění a dopadem na stav povrchových vod.

\section{ÚVOD}

Tento příspěvek pojednává o projektu „Cizorodé látky ve vodách podzemních, povrchových a odpadních jako důsledek lidské činnosti" (reg. číslo: CZ.071.02/0.0/ 0.0/16_040/0000378), v jeho části Predikce možného výskytu nebezpečných chemických látek při haváriích a povodních, riziko úniku látek závadných vodám a preventivní opatření - podklad k havarijnímu plánu. Účelem této části projektu je zlepšení informovanosti o výskytu látek nebezpečných vodám, definovaných jako látky prioritní a prioritní nebezpečné (dále též PPN látky) a vyhodnocení rizika pro hlavní město Prahu. Řešení se zaměřuje na specifickou skupinu chemických látek, které z hlediska šíření a akumulace v povodí představují nejvyšší riziko ohrožení.

Prioritní a prioritní nebezpečné látky představují významná rizika pro vodní prostředí spojená zejména s akutní a chronickou toxicitou pro vodní organismy, akumulací ve vodních ekosystémech, úbytkem přirozených stanovišt', snížením biologické rozmanitosti a $v$ neposlední řadě ohrožením lidského zdraví. Tyto látky byly poprvé jako skupina definovány ve formě seznamu v roce 2001 v př́loze č. X Rámcové směrnice o vodní politice [1], v současné době je platný seznam látek doplněný v roce 2013 [2], v současnosti se jedná celkem o 45 látek nebo skupin látek. Nebezpečnost těchto látek je permanentně prověřována a tento seznam se postupně rozšiřuje tak, jak se rozšiřuji znalosti o nových chemických látkách. Část těchto látek by měla být v budoucnosti pro svou vysokou nebezpečnost zakázána (prioritní nebezpečné látky) podle čl. 4 odst. 1 písm. a) bodu iv) Rámcové směrnice.

Projekt mapuje situaci od pramenů v celém povodí nad Prahou až po řeku VItavu v Praze. Skladování PPN látek a vypouštění odpadních vod s jejich obsahem představuje potenciální riziko pro životní prostředí, které se dále zvyšuje $\checkmark$ prrípadě mimořádných událostí.
Projekt vytvoří nástroje směřující ke zlepšení životního prostředí hlavního města Prahy. Sníži riziko spojené s prípadnými úniky PPN látek do vod tím, že poskytne podklady o miŕe nebezpečí a definuje látky, které mohou vodní toky $\checkmark$ Praze ovlivnit. Hlavní město tak získá přehled o možném znečištění vod látkami, které jsou z pohledu šiření vodním prostředím zásadní. Součástí projektu jsou i návrhy na další opatření včetně návrhů na doplnění havarijních plánů. Využití výstupů se předpokládá dále při rozhodovací činnosti krizového managementu pro zvýšení ochrany obyvatelstva.

\section{POSTUP ŘEŠENÍ}

Problematika PPN látek vyžaduje mimo jiné především orientaci ve složení a zařazení jednotlivých látek do skupin, ve kterých jsou analyzovány. Z tohoto důvodu byla $v$ projektu nejprve vytvořena přehledná tabulka, viz tabulku 1 , s názvy látek, výskytem a využíváním, prípadnou regulací (zákazem používání) a zařazením do skupin.

\section{VYPOUŠTĚNÍ ODPADNÍCH VOD S OBSAHEM PPN LÁTEK}

Vodní toky jsou recipientem PPN látek, které mj. mohou být do vodních toků vypouštěny spolu s odpadními vodami. Dalši šiření v říčním korytě je ovlivňováno prouděním vody, ale také pohybem říčních sedimentů, ve kterých mohou být tyto látky ve zvýšené míre akumulovány. Zvýšené riziko nadlimitních koncentrací PPN látek je tak za povodní a při zvýšených vodních stavech, kdy dochází k promíchávání sedimentů a k uvolňování látek v nich obsažených.

ISPOP (Integrovaný systém plnění ohlašovacích povinností) je zřízen zákonem č. 25/2008 Sb., o integrovaném registru znečištování životního prostredí a integrovaném systému plnění ohlašovacích povinností $\vee$ oblasti životního prostředí [5]. Zřizovatelem ISPOP a věcným garantem obsahu formulářu, tzn. ohlašovacích povinností, je Ministerstvo životního prostředí. Systém vyvijí a dodává společnost Telefónica Czech Republic, a. s., technický provoz a podobu aplikace ISPOP zajištuje CENIA, Česká informační agentura životního prostředí. ISPOP - data o vypouštěných odpadních vodách jsou předávána podle zákona o vodách § 38 odst. 4 (od 1. 1. 2018 podle odst. 6 novelizovaného zákona) [6]. 


\section{Číslo Název prioritní látky}

1$$
2
$$$$
3
$$$$
4
$$$$
-
$$

$$
\underline{5}
$$

\begin{tabular}{lll}
\hline 6 & kadmium a jeho sloučeniny & $\times$ \\
\hline $6 a$ & tetrachlormethan & \\
\hline 7 & chloralkany (C10-13) & $\times$ \\
\hline 8 & chlorfenvinfos & \\
\hline
\end{tabular}

\begin{tabular}{ll}
\hline 9 & chlorpyrifos \\
\hline $9 a$ & aldrin, dieldrin, endrin, isodrin
\end{tabular}

\begin{tabular}{ll}
$9 a$ & aldrin, dieldrin, endrin, isodrin \\
\hline $9 b$ & DDT, para-para-DDT \\
\hline 10 & $1,2-d i c h l o r e t h a n$
\end{tabular}

\begin{tabular}{ll}
\hline 10 & 1,2-dichlorethan \\
\hline 11 & dichlormethan \\
\hline 12 & bis(2-ethylhexyl)ftalát (DEHP) $\quad \times$ \\
\hline 13 & diuron
\end{tabular}

\begin{tabular}{|c|c|c|}
\hline 13 & diuron & \\
\hline 14 & endosulfan & $x$ \\
\hline 15 & fluoranthen & \\
\hline
\end{tabular}

\begin{tabular}{|c|c|c|c|c|}
\hline 16 & hexachlorbenzen & $x$ & 3 & fungicid, výroba rozpouštědel \\
\hline 17 & hexachlorbutadien & $x$ & 3 & $\begin{array}{l}\text { vedlejší produkt při výrobě chlorovaných uhlovodíků, rozpouštědlo, } \\
\text { výroba lubrikantů }\end{array}$ \\
\hline 18 & hexachlorcyklohexan & $x$ & 3 & insekticid \\
\hline 19 & isoproturon & & 1 & herbicid \\
\hline 20 & olovo a jeho sloučeniny & & 1 & $\begin{array}{l}\text { olověné akumulátory, ochranné slitiny před rentgenovými a gama } \\
\text { paprsky, munice, spalovací procesy, těžba, metalurgie a chemický } \\
\text { průmysl }\end{array}$ \\
\hline 21 & rtut’ a její sloučeniny & $x$ & 2 & $\begin{array}{l}\text { výroba chlóru, těžba zlata, zářivky, baterie, měřicí a analytické přístroje, } \\
\text { ochranná přisada různých nátěrů, spalování fosilních paliv a odpadů }\end{array}$ \\
\hline 22 & naftalen & & 1 & $\begin{array}{l}\text { výroba PVC, lepidel, léčiv, pryskyřic, maziv, barviv, součást uhelného } \\
\text { dehtu }\end{array}$ \\
\hline
\end{tabular}

\footnotetext{
* Legenda: 1 - použití povoleno, 2 - použití regulováno, 3- použití zakázáno
}

* Legend: 1 - use allowed, 2 - use regulated, 3 - use prohibited

\section{Regulace použití* \\ Výskyt, použití}

herbicid

barviva, plasty, nedokonalé spalování fosilních paliv

herbicid

automobilová doprava, rozpouštědlo, základní surovina pro výrobu

rady chemikálii (léčiva, plasty, kosmetika atd.)

3 zpomalovač hoření

2 slitiny, polovodiče, pájecí kovy

3 výroba tvrdých freonů, rozpouštědlo, průmyslový čisticí prostředek

2 plastifikátory, lubrikanty, obrábění kovů, zpracování kưže

3 akaricid, insekticid

$1 \quad$ insekticid

3 insekticidy

3 insekticidy

2 výroba vinylchloridu, rozpouštědlo

2 rozpouštědlo

1 změkčovadlo plastových výrobků

3 algicid, herbicid

$3 \quad$ insekticid

motorová nafta, výrobky z černouhelného dehtu, asfalt, materiály pou-

žívané při pokrývání střech a stavbě silnic

fungicid, výroba rozpouštědel

vedlejší produkt při výrobě chlorovaných uhlovodíků, rozpouštědlo, yroba lubrikantu

olověné akumulátory, ochranné slitiny před rentgenovými a gama paprsky, munice, spalovací procesy, těžba, metalurgie a chemický prümys ochranná prísada různých nátěrů, spalování fosilních paliv a odpadů dehtu 


\section{Číslo Název prioritní látky}

\begin{tabular}{|c|c|c|c|c|}
\hline Císlo & Název prioritní látky & nebezpečná látka & použití* & Výskyt, použití \\
\hline 23 & nikl a jeho sloučeniny & & 3 & výroba slitin, baterie, mince a šperky, magnety, pokovování \\
\hline 24 & nonylfenoly & $x$ & 3 & povrchově aktivní látky, změkčovadla plastů \\
\hline 25 & oktylfenoly & & 3 & výroba stabilizátorů, změkčovadel, antioxidantů, tenzidů \\
\hline 26 & pentachlorbenzen & $x$ & 3 & fungicid, zpomalovač hoření \\
\hline 27 & pentachlorfenol & & 3 & pesticid \\
\hline 28 & $\begin{array}{l}\text { polyaromatické uhlovodíky } \\
\text { (PAU) }\end{array}$ & $x$ & 2 & nedokonalé spalování \\
\hline 29 & simazin & & 3 & herbicid \\
\hline $29 a$ & tetrachlorethylen & & 1 & rozpouštědlo organických látek \\
\hline $29 b$ & trichlorethylen & & 2 & průmyslové rozpouštědlo \\
\hline 30 & tributylcín a jeho sloučeniny & $x$ & 2 & dřevo chránící přípravky, nátěry lodí \\
\hline 31 & trichlorbenzeny & & 3 & $\begin{array}{l}\text { výroba pigmentů a barviv, dřive masivně používány jako pesticidy } \\
\text { a chladicí kapaliny }\end{array}$ \\
\hline 32 & trichlormethan (chloroform) & & 1 & výroba fenolu, extrakční činidlo \\
\hline 33 & trifluralin & $x$ & 3 & herbicid \\
\hline 34 & dikofol & $x$ & 3 & akaricid \\
\hline 35 & $\begin{array}{l}\text { perfluoroktansulfonová kyse- } \\
\text { lina a její deriváty (PFOS) }\end{array}$ & $x$ & 3 & surfaktant \\
\hline 36 & chinoxyfen & $x$ & 1 & fungicid \\
\hline 37 & $\begin{array}{l}\text { dioxiny a sloučeniny s dioxino- } \\
\text { vým efektem }\end{array}$ & $x$ & 3 & $\begin{array}{l}\text { spalování fosilních paliv a odpadu, průmyslová výroba, kde se vyskytuje } \\
\text { chlór (chemický, textilní, papírenský) }\end{array}$ \\
\hline 38 & aklonifen & & 1 & herbicid \\
\hline 39 & bifenox & & 1 & herbicid \\
\hline 40 & cybutryn & & 3 & fungicid \\
\hline 41 & cypermethrin & & 1 & insekticid \\
\hline 42 & dichlorvos & & 3 & insekticid \\
\hline 43 & $\begin{array}{l}\text { hexabromcyklododekany } \\
\text { (HBCDD) }\end{array}$ & $x$ & 3 & zpomalovače hoření \\
\hline \multirow{2}{*}{44} & \multirow{2}{*}{ heptachlor a heptachlorepoxid } & \multirow{2}{*}{$x$} & 3 & insekticid \\
\hline & & & 3 & vznik přeměnou heptachloru \\
\hline 45 & terbutryn & & 3 & herbicid \\
\hline
\end{tabular}

$\begin{array}{ll}\text { Prioritní } & \text { Regulace } \\ \text { nebezpečná látka } & \text { použití }^{*}\end{array}$

$\begin{array}{ll}\text { Prioritní } & \text { Regulace } \\ \text { nebezpečná látka } & \text { použití }^{*}\end{array}$

Výskyt, použití 


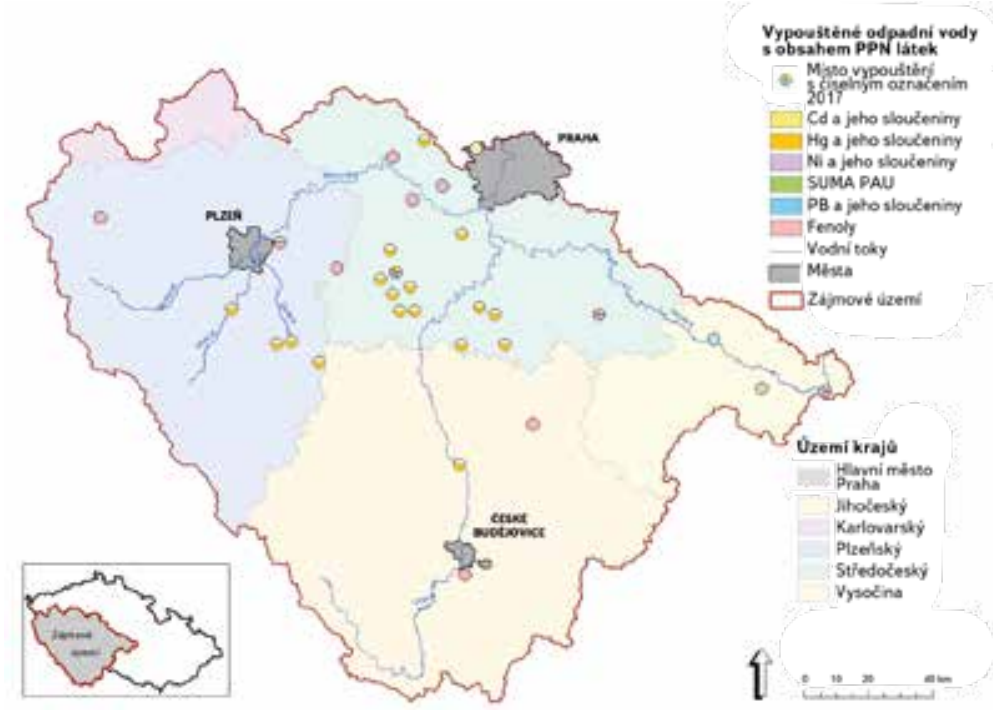

Obr. 1. Místa vypouštění odpadních vod obsahujících PPN látky (mimo AOX) v zájmovém území v roce 2015

Fig. 1. Places of waste water outflow containing PPH substances (outside AOX) in the area of interest in 2015

Současné znění vodního zákona [7], § 38 odst. 4 zní: Kdo vypouští odpadní vody do vod povrchových nebo podzemních, je povinen v souladu s rozhodnutím vodoprávního úřadu měřit objem vypouštěných vod a míru jejich znečištění a výsledky těchto měření předávat vodoprávnímu úřadu, který rozhodnutí vydal, príslušnému správci povodí a pověrenému odbornému subjektu. Vodoprávní úřad tímto rozhodnutím stanoví místo a způsob měření objemu a znečištění vypouštěných odpadních vod a četnost předkládání výsledků těchto měření.

Data o vypouštěném znečištění v zájmovém povodí byla v projektu zpracována za období let 2014 a 2015. Data za rok 2017 slouží jako kontrolní v prípadě problematické identifikace subjektu, lokalizace nebo číselných hodnot. Z databáze vyplývá, že do vodních toků zájmového území jsou vypouštěny odpadní vody s možným obsahem následujících látek:

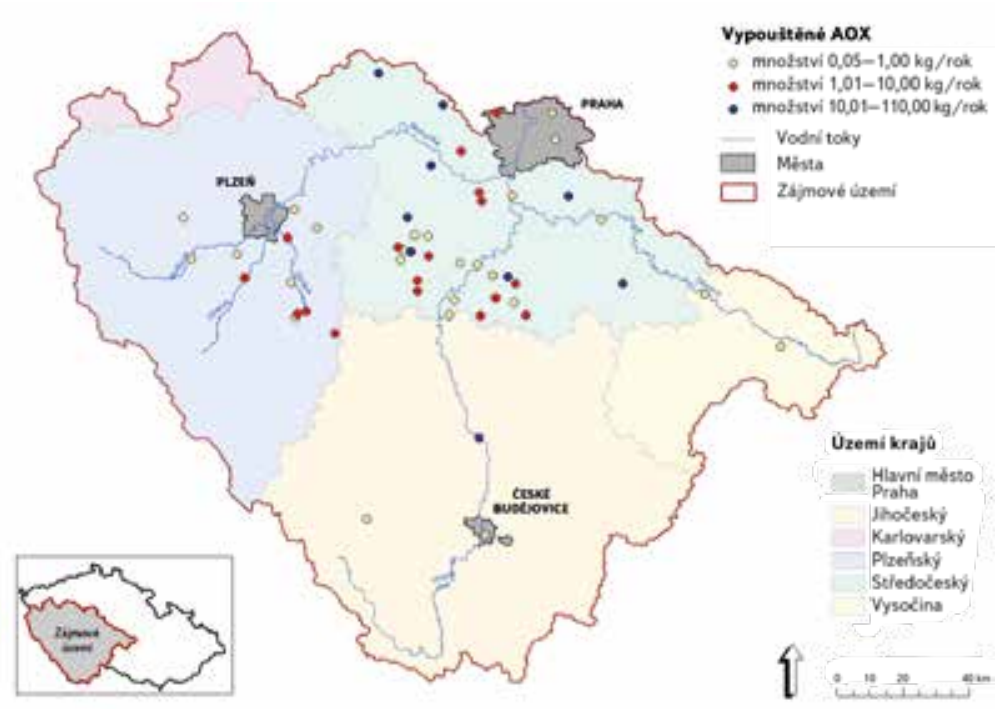

Obr. 2. Místa vypouštění odpadních vod obsahujících AOX v zájmovém území $\checkmark$ roce 2015

Fig. 2. Places of waste water outflow containing AOX in the area of interest in 2015

- fenoly,

- AOX - adsorbovatelné organicky vázané halogeny (podrobnější informace jsou uvedeny níže),

- nepolární extrahovatelné látky,

- kadmium a jeho sloučeniny,

- nikl a jeho sloučeniny,

- suma PAU,

- rtut a její sloučeniny,

- uhlovodíky $C_{10}-C_{40^{\prime}}$

- olovo a jeho sloučeniny.

Halogenové organické sloučeniny (AOX) jsou poměrně širokou skupinou. Jde o mezinárodně uznávaný parametr; může se jednat o jednoduché sloučeniny jako je chloroform, chlorfenoly, chlorbenzeny i komplexní organické molekuly, jako jsou dioxiny a furany (PCDD, PCDF) s nejrůznějšími toxickými

Tabulka 2. Limitní hodnoty pro vybrané látky

Table 2. Limit values for selected substances

\begin{tabular}{|c|c|c|c|}
\hline Č. & Vypouštěné látky do vod & $\begin{array}{l}\text { NEK-RP (norma env. kvality - } \\
\text { roční průměr) mg/I }\end{array}$ & Způsob definování hodnoty NEK-RP \\
\hline 1 & fenoly & 3 & Tab. 1 c, NV č. 401/2015 Sb., Př́loha č. 3 \\
\hline 2 & $\begin{array}{l}\text { adsorbovatelné organicky vázané } \\
\text { halogeny }\end{array}$ & 25 & Tab. 1 c, NV č. 401/2015 Sb., Příloha č. 3 \\
\hline 3 & kadmium a jeho sloučeniny & 0,08 (třída 2) & Tab. 1 b, NV č. 401/2015 Sb., Př́loha č. 3 \\
\hline 4 & nepolární extrahovatelné látky & 100 & podle dřive platného NV \\
\hline 5 & nikl a jeho sloučeniny & 4 & Tab. 1 b, NV č. 401/2015 Sb., Príloha č. 3 \\
\hline 6 & PAU - suma (ČSN 757221) & 0,1 & Tab. 1 c, NV č. 401/2015 Sb., Př́loha č. 3 (pro vodárenské účely) \\
\hline 7 & rtut’ a její sloučeniny & 0,05 & podle odborného odhadu \\
\hline 8 & uhlovodíky $C_{10}-C_{40}$ & 100 & Tab. 1 c, NV č. 401/2015 Sb., Př́loha č. 3 \\
\hline 9 & olovo a jeho sloučeniny & 1,2 & Tab. 1 b, NV č. 401/2015 Sb., Příloha č. 3 \\
\hline
\end{tabular}


vlastnostmi. V prírodě se většina AOX přirozeně nevyskytuje, jejich hlavním zdrojem $v$ prostředí je především průmyslová výroba papíru a celulózy. Konkrétní chemické i toxikologické vlastnosti jsou vždy závislé na druhu sloučeniny; souhrnně popsat negativní účinek AOX je prakticky nemožné. Obecně se ale dají tyto látky považovat za toxické pro vodní organismy, schopné bioakumulace, s různou mírou toxicity pro člověka. Mezi méně významné zdroje AOX můžeme zařadit také chlorování pitné vody a v podstatě jakýkoliv chemický závod, kde dochází ke zpracování chlóru a jiných halogenů. Převážná část AOX však uniká do prostředí prostřednictvím odpadních vod [8].

Přehledné informace, vztahující se k místům vypouštění odpadních vod s možným obsahem PPN látek, informace o znečištovateli, datu vydání a ukončení platnosti příslušného rozhodnutí k vypouštění odpadních vod, skutečně vypouštěné množství v daném roce, počet měření a další podrobnosti jsou uvedeny v podrobných tabulkách integrovaného registru, vedeného podle [9]. Pro přehled je připojena následující mapka - obr. 1 .

Vypouštěné znečištění, evidované v databázi ISPOP, neumožňuje v řadě případů jednoznačné zjištění, zda jsou PPN látky v odpadních vodách prítomné. Zvláště nejednoznačné je to $v$ prípadě vypouštění $A O X$, fenolů, $C_{10}-C_{40}$ a NEL. Místa vypouštění odpadních vod s obsahem AOX jsou vyznačena v následující mapce - obr.2.

Bilance vypouštěného ročního množství odpadních vod s obsahem PPN látek bude konfrontována s látkami vypouštěnými podle E-PRTR registru [10]. Rizikovost vypouštěných odpadních vod s obsahem PPN látek Ize hodnotit podle následující tabulky, viz tabulku 2, vycházející z norem environmentální kvality pro útvary povrchových vod.

\section{SPECIFIKACE SKLADOVANÝCH PPN LÁTEK}

Kromě prímého vypouštění odpadních vod se mohou do vodních toků dostávat sledované látky také z míst, kde je s nimi nakládáno v technologickém provozu, nebo kde jsou skladovány. Předávání dat o skladování látek je povinné

Tabulka 3. Přehled PPN látek a SZL zjištěných v povrchových vodách, jejichž hodnoty nejčastěji prekračuji NEK-RP anebo NEK-NPK

Table 3. Overview of PPH substances and specific pollutants detected in surface waters whose values most frequently exceed EQS-RP or EQS-NPK limits

\section{Č. látky}

podle Př́lohy č. 6

k NV č. 401/2015 Sb.

\begin{tabular}{|c|c|c|c|}
\hline 1 & alachlor ${ }^{+}$ & $x$ & $x$ \\
\hline 2 & anthracen $^{+}$ & & \\
\hline- & AOX & $x$ & $x$ \\
\hline součástí PAU č. látky 28 & benzo(a)pyren+ & $x$ & $x$ \\
\hline součástí PAU č. látky 28 & $\begin{array}{l}\text { benzo(ghi) } \\
\text { perylen }\end{array}$ & $x$ & $x$ \\
\hline
\end{tabular}

\begin{tabular}{llll}
\hline 13 & diuron $^{+}$ & & \\
\hline 15 & fluoranthen $^{+}$ & $\times$ & $\times$ \\
\hline 18 & $\begin{array}{l}\text { hexachlorcy- } \\
\text { klohexan (SUMA) }\end{array}$ & \\
\hline & metolachlor $\quad \times$
\end{tabular}

+NEK podleNV č. 401/2015 Sb., Přiloha č. 3, tabulka 1c

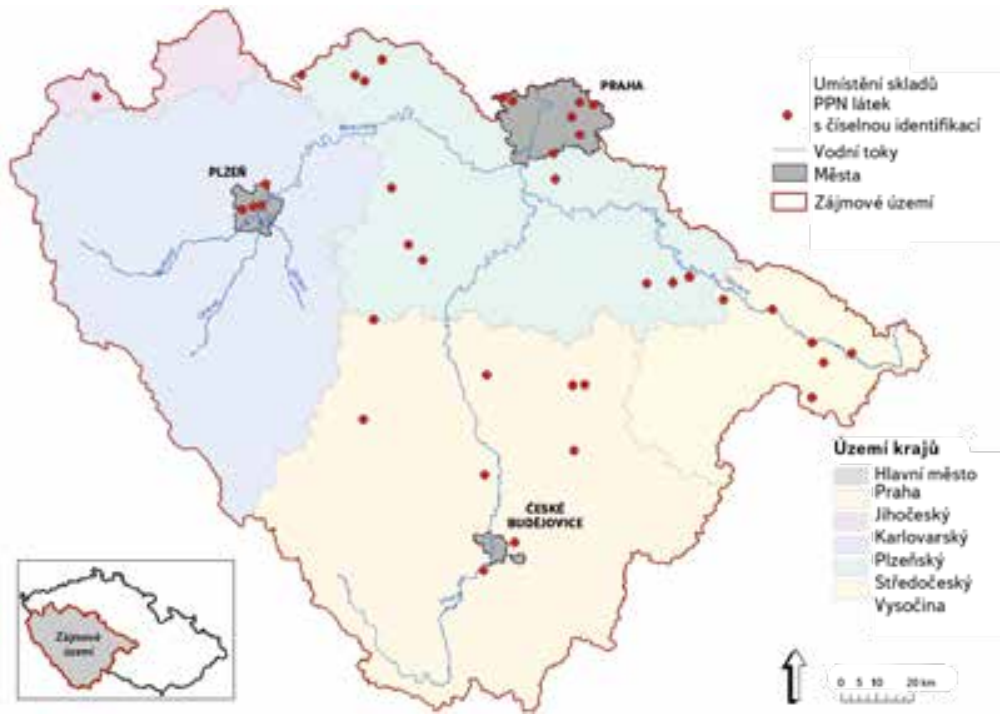

Obr. 3. Umístění skladů, objektů a zařízení s nebezpečnými látkami zařazenými do skupiny A nebo B

Fig. 3. Location of warehouses, buildings and facilities containing hazardous substances classified in group A or B

podle zákona o prevenci závažných havárií [11]. Zpracovatelé získali nejdřive podklady o místech skladování nebezpečných látek z databáze eSPIRS (Seveso Plant Information Retrieval System - systém Seveso pro získávání informací o zařízeních), které spravuje Společné výzkumné centrum v EU (JRC), podrobněji [12].

Ze získaných informací bylo třeba určit, které skladované materiály obsahují PPN látky, v jakém množství a na jakém místě se nacházejí. Pro zpřesnění informací byly informace požadovány také od príslušných krajských úřadů, které mají tuto agendu sledovat podle zákona o prevenci závažných havárií č. 224/2015 Sb. [11]. Místa byla dále konfrontována se skutečným umístěním pro identifikaci bodových zdrojů znečištění v mapách. Rozmístění skladů na území krajů je patrné z obr. 3.

\section{POSOUZENÍ RIZIKOVOSTI SKLADOVÁNÍ PPN LÁTEK Z POHLEDU ŘÍČNÍ POVODNĚ NEBO POVODNÍ Z PŘIVALOVÝCH SRÁŽEK}

Při dodržení všech legislativních omezení jsou skladovací místa z pohledu znečištování povrchových a podzemních vod bezpečná. V rámci rizika možného úniku sloučenin s obsahem PPN látek ve skladujících místech při zvýšených vodních stavech ve vodních tocích bylo posuzováno umístění skladů v záplavovém území. Záplavová území jsou administrativně určená území, která mohou být při výskytu řiční povodně zatopena vodou. Rozsah záplavového území schvaluje na návrh správce vodního toku vodoprávní úrad. Záplavové území odpovídá príibližně průtokům stoleté vody $-Q_{100}$. Z posouzení vyplynulo, že žádné místo (objekt, zařízení), kde jsou nebezpečné látky skladovány, neleží ve vyhlášeném záplavovém území.

\section{STÁVAJIICÍ MONITOROVACÍ SYSTÉMY KVALITY POVRCHOVÝCH VOD}

V České republice se monitoringem výskytu PPN látek ve vodách zabývají subjekty, které jsou zodpovědné za pořizení plánů dílčích povodí. Státní podniky Povodí monitorují kvalitu vod útvarů povrchových vod a následně vyhodnocují stav vod. Ve spolupráci s vodoprávními úřady pak príslušné krajské úřady schvalují plány v rámci své územní působnosti. 
V zájmovém území monitoring provádí především státní podnik Povodí Vltavy. Řešený projekt na tento monitoring navazuje, zabývá se podrobněji bodovými zdroji znečištění, kvalitou říčních sedimentů a možným dalším ohrožením vodních toků, prípadnými úniky při mimořádných událostech.

Na základě rady informací, predevším podle zpráv hodnotících období 2015-2016, Ize v zájmovém území shrnout informace o výskytu těchto látek ve vodních tocích následovně:

— Analyzované PPN látky a SZL (specifické znečištujuící látky uváděné v [4]) sledované v povrchových vodách ČR se vyskytují prevážně ve velmi nízkých koncentracích na úrovni mezí stanovitelnosti (MS) prístrojü.

— Pokud jsou zjištěny hodnoty nad MS, pak většinou nepřesahují NEK-RP (norma environmentální kvality vyjádřená jako roční průměrná hodnota) a NEK-NPK (norma environmentální kvality vyjádřená jako nejvyšší príipustná koncentrace). Limitní hodnoty NEK-RP a NEK-NPK jsou uvedeny pro jednotlivé látky v [4].

- Obsah některých látek (benzo(a)pyren, cypermethrin, dicofol nebo dichlorvos) není možné vyhodnotit, jelikož mez stanovitelnosti dané analytické metody je často vyšší než NEK (hodnota NEK-RP nebo NEK-NPK) pro danou sledovanou látku.

— Při orientačním porovnání s hodnotami NEK (NV č. 401/2015 Sb., Přiloha č. 3, tabulka 1 b a 1 c) je $v$ povrchových vodách nejčastěji překročena hodnota NEK-RP anebo NEK-NPK u látek uvedených v následující tabulce - tabulka 3.

— Z literárních údajů vyplývá, že sedimenty obsahují vyšší koncentrace PPN látek a specifických znečištujících látek než povrchová voda. Nad mezí stanovitelnosti jsou stanovovány koncentrace těžkých kovů a některé látky ze skupiny PAU, jejichž výskyt je ve vodách i sedimentech zaznamenáván pravidelně, a to i ve zvýšených koncentracích.

- Na řadě vodních toků jsou dlouhodobě zjištovány zvýšené hodnoty AOX. Těkavé organické látky (TOL) se vyskytují v povrchových vodách v nízkých koncentracích. Látky ze skupiny PCB (polychlorované bifenyly) se $v$ matrici povrchové vody prakticky neobjevují. Problémem celorepublikovým jsou látky ze skupiny PAU, z nichž benzo(ghi)perylen se v tocích objevuje v nadlimitních koncentracích nejčastěji. Hodnoty překračující NEK byly zjištěny také u Ehexachlorcyklohexanů a lindanu (OCP), anthracenu, benzo(b)fluoranthenu, fluoranthenu, fenanthrenu a benzo(a)pyrenu (ze skupiny PAU).

- Nejčastěji se vyskytující pesticidní látky v povrchových vodách jsou metabolity metolachloru, acetochloru, alachloru a $v$ prípadě terbutylazinu metabolity i základní látka [5]. Často se jedná o účinné látky prípravků spojených s pěstováním ozimé repky a kukuřice. Jsou patrné rozdíly mezi oblastmi s intenzivní rostlinnou výrobou a horskými, převážně zalesněnými povodími. Znečištění jednotlivými látkami během roku kolísá v závislosti na ročním období, srážkovém režimu apod. Hodnoty NEK jsou překračovány i u diuronu a isoproturonu.

Množství vypouštěných odpadních vod s obsahem PPN látek z velkých zdrojů znečištění, které se dostávají do vodních tokü, bude konfrontováno s daty za rok 2016 z databáze E-PRTR (evropský registr úniků a přenosủ znečišt’ujících látek) [10].

Velmi podrobně se různými zdroji znečištění včetně zdrojů PPN látek a jejich dopadem na stav vodních útvarů zabývají správci povodí při přípravě plánů oblasti povodí a plánů dílíich povodí. Jsou zde soustředěny výsledky jejich vlastního monitoringu a šetření u znečištovatelů i výsledky dalších dílčích studií. Pro zájmové území řešeného projektu jsou tyto plány zveřejněny na internetových stránkách Povodí Vltavy [13].

Povodňové události, které proběhly na území ČR v uplynulých letech, vedly ke zkoumání těchto jevů nejen co do množství vod a rozsahu rozlivů. Byla zjištována a posuzována i jakost povodňových vod včetně zdrojů znečištění a způsobů jeho šíření. Tyto poznatky vedly k některým zevšeobecněním a návrhưm vhodných postupů, viz např. [14] nebo [15]. Současně se však ukazuje, že každá povodňová událost je specifická, a pokud chceme zabránit šírení znečištění nebezpečnými látkami ze známého zdroje, je třeba soustředit ochranná opatření zejména do místa vzniku či uskladnění těchto látek.

\section{VÝSKYT PPN LÁTEK V ŘíČNÍCH SEDIMENTECH}

Využitelnost všech výše uvedených zdrojů informací byla vzata v úvahu. S ohledem na cíle projektu byla hodnocena návaznost údajů o zdrojích znečištění a dopadech ve formě zhoršené kvality vody v tocích.

Identifikace nebezpečných látek ve vodách je často obtížná s ohledem na stopové koncentrace na úrovni meze stanovitelnosti prístrojového vybavení laboratoří. V sedimentech a jemných plaveninách může u některých látek docházet ke kumulaci, proto se ve vybraných profilech monitoringu jakosti povrchových vod odebírají i vzorky této matrice. Pravidelný monitoring v zájmovém území provádí správce toku podnik Povodí Vltavy. Několikaleté velmi podrobné, celorepublikové sledování včetně bioakumulace řešil také Český hydrometeorologický ústav [16].

Aby bylo umožněno odhadnout pravděpodobnost výskytu nebezpečných látek při mimořádných událostech pro profil Vltavy $v$ Praze, bylo rozhodnuto podrobněji sledovat složení ríčních sedimentů v závěrečných úsecích hlavních toků nad Prahou.

Před samotným zahájením odběrů vzorků řičních sedimentů proběhlo vytipování vhodných míst v zájmovém území Středočeského kraje v blízkosti hlavního města. Kritériem bylo nalézt lokality, které by pokryly zdroje vypouštějící odpadní vody s obsahem PPN látek do vodních toků zájmového území. Dalším velmi důležitým kritériem, které významně ovlivnilo výběr vlastních lokalit, byla znalost míst, která umožňují akumulaci říčních sedimentů. Protože sedimenty se ve zvýšené míre vyskytují ve vodních tocích se sníženou rychlostí vody, která je následně přičinou sedimentace plavených částic, byla vybrána místa v nadjezí vodních toků. Posledním kritériem byla samotná prístupnost odběrných míst. Na základě uvedených kritérií byla v rámci řešení vybrána čtyři odběrná místa:

- Vltava-Štěchovice nad jezem, místo u hráze vodního díla;

— Vltava-Modřany nad jezem, jako závěrné místo, ve kterém se předpokládá případné ovlivnění z př́tokủ řek Berounky a Sázavy;

- Berounka-Černošice nad jezem, významný levobřežní prítok Vltavy, místo v nadjezí elektrárny v Černošicích;

- Sázava-Žampach nad jezem, významný pravobřežní prítok Vltavy.

Odběrná místa jsou vyznačena v ortofotografických mapkách - obr. 4. Závěrečné odběrné místo na VItavě je zachyceno na fotografii - obr. 5.
SÄZAVA - ZAMPACHNAD JEZESM

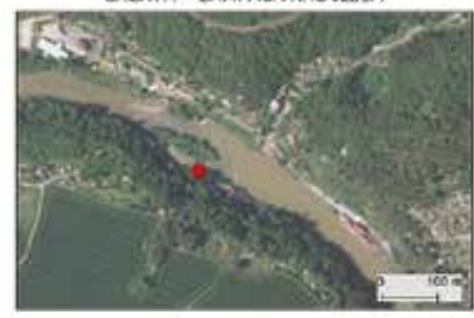

VLTAVA - MODAAANY NAD MEZEM

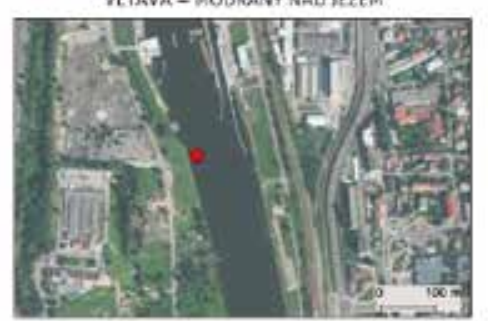

VLTAVA - STECHOVCE NAD ILZEM

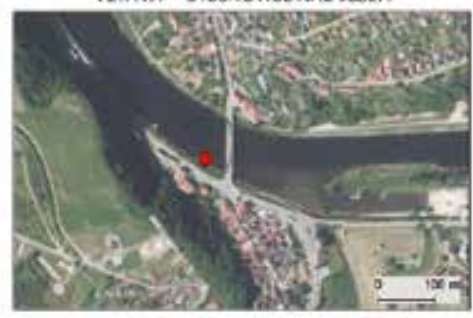

BERCUNKA- CERNOSICE NAD IEZEM

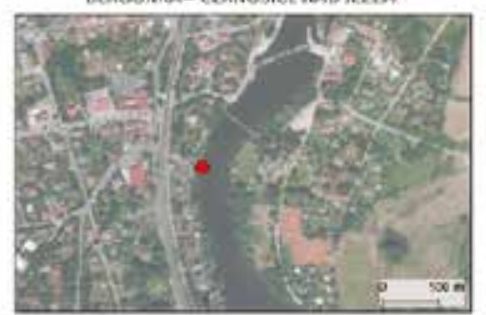

Obr. 4. Monitoring sedimentů ve vybraných lokalitách

Fig. 4. Sediment monitoring in selected localities 


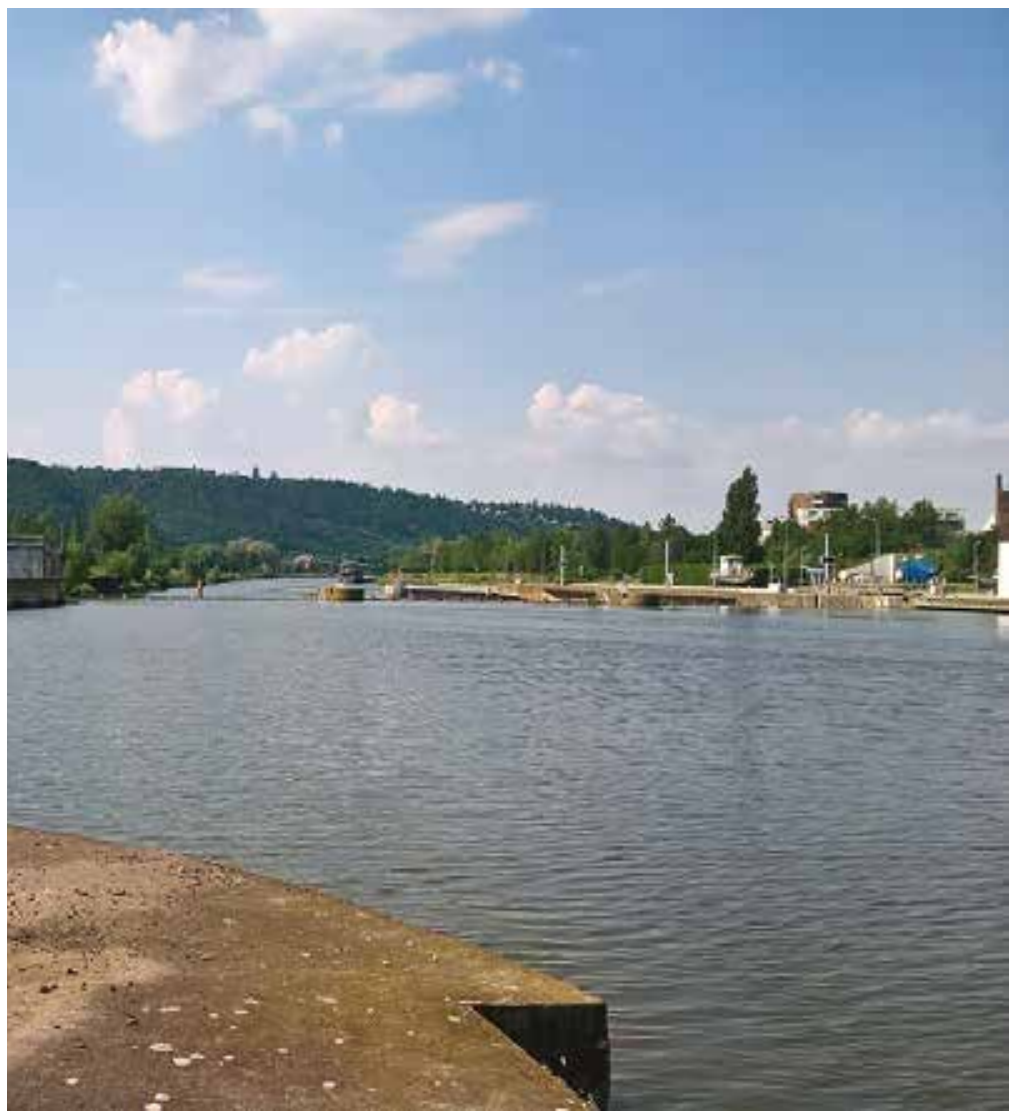

Obr. 5. Vltava-Modřany, jezová zdrž

Fig. 5. Vltava-Modřany, weir catch basin

Odběry vzorků sedimentů v těchto lokalitách a jejich laboratorní zpracování probíhalo v období 2018-2019. V současné době jsou tyto výsledky vyhodnocovány pro využití ve výstupech projektu.

\section{DISKUSE}

Znalosti o PPN látkách jsou všeobecně nedostatečné už proto, že se tyto látky postupně nově identifikují, celá skupina se postupně rozšiřuje a jen malé procento laboratoři dokáže tyto nové látky v prvotní fázi identifikace analyzovat s požadovanou přesností. Jedná se o dlouhodobý proces monitorující stav výskytu PPN látek - jejich pohyb ve vodním prostředí a hodnocení negativních dopadů. Legislativní proces má určitou setrvačnost a jistě nelze očekávat, že změny v prílohách evropských směrnic se okamžitě promítnou až k jednotlivým výrobním subjektům a do změn v jejich technologiích. Firmám většinou vyhovuje současný stav, kdy na stanovení jednotlivých látek mají nasmlouvány specializované laboratoře a nové požadavky by jim většinou přinášely zpřísnění hodnot ve vodohospodářských rozhodnutích. Odběry a rozbory ke zjištění míry znečištění vypouštěných odpadních vod mohou provádět jen odborně způsobilé osoby oprávněné k takovému podnikání. Většina laboratorních analýz vyžaduje drahé přístrojové vybavení a průběžný odborný servis, aby mohly být PPN látky měřeny při zachování požadovaných nízkých mezí stanovitelnosti.

Jedním z dalších poznatků je, že mnohé firmy ale i úřady mají zábrany poskytovat již jednou získané výsledky nejen veřejnosti ale i odborné výzkumné instituci pod záminkou obrany proti konkurenci. Někdy tato neochota vede k nutnosti pořizovat terénními pracemi vlastní data.

\section{ZÁVĚR}

Výsledky řešeného projektu nejsou určeny k prímému komerčnímu využití. Hlavním prínosem má být zvýšení znalostí o výskytu PPN látek v prostředí, o jejich šírení a o procesech, které toto šiřrení ovlivňují. Projekt kombinuje oficiální informace od znečištovatelů, data ze standardních monitoringů prostředí a údaje zjištěné vlastním podrobným výzkumem tak, aby mohl poskytnout reálný pohled na rizika a ohrožení toku Vltavy v hlavním městě.

Řešení je zaměřeno na velkou plochu zájmového území České republiky, která vyžaduje zpracování rozsáhlého množství dat.

Databáze a monitorovací programy vedené v současné době jsou velmi cenné, jsou však přizpůsobeny účelu, pro který byly zřízeny, tedy zejména pro reportování do evropských struktur. Proto je z nich často obtí̌né nalézt souvislosti mezi konkrétním znečištovatelem a zjištěním nadlimitních koncentrací $\checkmark$ monitorovaném místě.

Posílení současných znalostí je tedy potřebné ve smyslu hledání souvislostí mezi konkrétním zdrojem znečištujících látek a dopadem této zátěže na vodní tok. Součástí výstupů rešeného projektu budou proto doporučení směřující do činnosti vodoprávních orgánů i návrhy, náměty a požadavky na úpravu některých zmiňovaných národních databází a monitorovacích programů.

\section{Literatura}

[1] Směrnice Evropského parlamentu a Rady 2000/60/ES

[2] Směrnice Evropského parlamentu a Rady 2013/39/EU.

[3] Dostupné z: https://www.irz.cz/

[4] Nařizení vlády č. 401/2015 Sb

[5] JURÁŇ, S. Analýza proveditelnosti. Čistá voda-zdravé město, koncept č. III, Brno, 2018.

[6] Dostupné z: https://www.ispop.cz/magnoliaPublic/cenia-project/uvod.html

[7] Zákon č. 254/2001 Sb., vodní zákon.

[8] Dostupné z: https://arnika.org/halogenovane-organicke-slouceniny-aox

[9] Zákon č. 25/2008 Sb., o integrovaném registru znečištování životního prostředí a integrovaném systému plnění ohlašovacích povinností v oblasti životního prostředí.

[10] Evropský registr úniků a přenosů znečištujících látek E-PRTR.

[11] Zákon o prevenci závažných havárií č. 224/2015 Sb.

[12] Dostupné z: https://minerva.jrc.ec.europa.eu/EN/espirs/public/publicsearch

[13] Dostupné z: http://www.pvl.cz/planovani-v-oblasti-vod

[14] DRBAL, K. a kol. Metodika mapovánípovodňového rizika. Usnesení Vlády České republiky ze dne 21. prosince 2009 č. 1573 ke Zprávě o vyhodnocení povodně v červnu a červenci 2009 na území České republiky.

[15] JURÁŇ S. a kol. Činnost povodňových komisí, složek IZS a ostatnich účastníků pred povodněmi. Usnesení vlády České republiky ze dne 3. července 2013 č. 533.

[16] Dostupné z: http://hydro.chmi.cz/isarrow/ 
Autoři

Ing. Stanislav Juráň

凶stanislav.juran@vuv.cz

Ing. Milena Forejtníková

凶milena.forejtnikova@vuv.cz

Ing. Lucie Vysloužilová

凶lucie.vyslouzilova@vuv.cz

Mgr. Kateřina Sovová, Ph.D.

凶katerina.sovova@vuv.cz

Výzkumný ústav vodohospodářský T. G. Masaryka, v. v. i., pobočka Brno

Příspěvek prošel lektorským řízením.
THE CLEAN WATER - A HEALTHY

CITY: THE USABILITY OF THE EXISTING INFORMATION COLLECTION SYSTEM TO FULFILLMENT OF GOALS

\section{JURAN, S.; FOREJTNIKOVA, M.; VYSLOUZILOVA, L.; SOVOVA, $K$.}

TGM Water Research Institute, p.r.i., Brno Branch

Keywords: surface water quality - river sediments pollution sources - thematic data bases

The contribution is part of the Clean Water - a Healthy City project, which deals with the prediction of the possible occurrence of hazardous chemicals during the accidental pollution and floods. Lists the databases that are currently on the subject and with their practical applicability. In the case of the VItava River in Prague, human activities and methods of management in the river basin over this town, it describes the possibilities of predicting the occurrence of dangerous substances in the flow area in the capital. It justifies the need to introduce temporary tracking profiles for the purpose of solving the research task. It proposes the principles to complement existing monitoring networks and pollution sources databases in order to better assess the relationship between pollution sources and the impact on surface water status. 